\title{
Methylene Blue Immobilized on Cellulose Acetate with Titanium Dioxide: an Application as Sensor for Ascorbic Acid
}

\author{
Andrea A. Hoffmann, ${ }^{a}$ Silvio L. P. Dias, ${ }^{*, a}$ Jordana R. Rodrigues, ${ }^{a}$ Flavio A. Pavan, ${ }^{b}$ \\ Edilson V. Benvenutti ${ }^{a}$ and Eder C. Lima ${ }^{a}$
}

\author{
${ }^{a}$ Instituto de Química, Universidade Federal do Rio Grande do Sul, 91501-970 Porto Alegre-RS, Brazil \\ ${ }^{b}$ Universidade Federal do Pampa, Bagé-RS, Brazil
}

\begin{abstract}
Neste trabalho, o corante azul de metileno foi imobilizado na superfície do acetato de celulose modificado com dióxido de titânio produzindo um material híbrido sólido denominado de CA-TiO 2 MB. O experimento produziu uma quantidade de $1,8 \mathrm{mmol} \mathrm{g}^{-1} \mathrm{de} \mathrm{TiO}_{2}$ incorporado no acetato de celulose e uma quantidade de 0,170 o $0,005 \mathrm{mmol} \mathrm{g}^{-1}$ de azul de metileno adsorvido na superfície do $\mathrm{CA}-\mathrm{TiO}_{2}$. Um eletrodo de pasta de carbono desse material foi usado para estudar a oxidação eletrocatalítica do ácido ascórbico pelas técnicas de voltametria cíclica e cronoamperometria. $\mathrm{O}$ pH da solução não afetou o potencial de pico de anódico nem a corrente de pico anódico ao variar de 3,0 a 7,0. A oxidação do analito ocorreu em $75 \mathrm{mV}$ versus ECS em solução de $\mathrm{KCl}$ 1,0 mol L-1 e pH 7,0. A intensidade da corrente de pico anódico variou com a concentração de ácido ascórbico na faixa de 5,0 r $10^{-4} \mathrm{~mol} \mathrm{~L}^{-1}$ to $4,5 \mathrm{r} 10^{-3} \mathrm{~mol} \mathrm{~L}^{-1}$, sendo observada uma correlação linear com um limite de detecção de $15 \mu \mathrm{mol} \mathrm{L}^{-1}$, limite de quantificação de $50 \mu \mathrm{mol} \mathrm{L}^{-1}$ e uma sensibilidade de $7,1 \mu \mathrm{A} \mathrm{L} \mathrm{mol}^{-1}$. A resposta do eletrodo foi muito rápida, com um tempo decorrido de $1,0 \mathrm{~s}$, mostrando potencial para ser utilizado como um sensor eletroquímico para a determinação de ácido ascórbico em produtos comerciais.
\end{abstract}

In this work, methylene blue dye was immobilized on the surface of cellulose acetate modified with titanium dioxide, producing a solid hybrid material designated as $\mathrm{CA}-\mathrm{TiO}_{2} \mathrm{MB}$. The experiment yielded an amount of $1.8 \mathrm{mmol} \mathrm{g}^{-1}$ of $\mathrm{TiO}_{2}$ incorporated in the cellulose acetate and an amount of $0.17000 .005 \mathrm{mmol} \mathrm{g}^{-1}$ of methylene blue adsorbed onto $\mathrm{CA}-\mathrm{TiO}_{2}$ surface. A carbon paste electrode of this material was used to study the electrocatalytic oxidation of ascorbic acid by cyclic voltammetric and chronoamperometric techniques. The $\mathrm{pH}$ of the solution had no effect on the anodic peak potential and anodic peak current when ranging from 3.0 to 7.0. The oxidation of the analyte occurred at $75 \mathrm{mV}$ versus $\mathrm{SCE}$ in $1.0 \mathrm{~mol} \mathrm{~L}^{-1} \mathrm{KCl}$ solution and $\mathrm{pH}$ 7.0. The intensity of the anodic peak current varied with the concentration of ascorbic acid from $5.0 \mathrm{r} 10^{-4} \mathrm{~mol} \mathrm{~L}^{-1}$

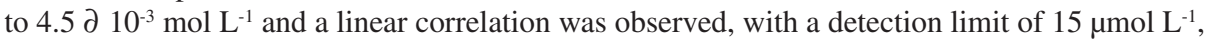
quantification limit of $50 \mu \mathrm{mol} \mathrm{L^{-1 }}$ and a sensitivity of $7.1 \mu \mathrm{A} \mathrm{L} \mathrm{mol}{ }^{-1}$. The electrode response was very fast, with an elapsed time of about $1.0 \mathrm{~s}$, showing the potentiality to be utilized as an electrochemical sensor for determination of ascorbic acid in commercial samples.

Keywords: methylene blue, modified cellulose acetate, titanium dioxide, carbon paste electrode, ascorbic acid

\section{Introduction}

The development of sensors that allow the measurements of some analyte, which presents analytical or environmental interest, has continued to be of major concern during the past two decades. They use as electrochemical mediator species makes possible

*e-mail: silvio@iq.ufrgs.br the attempt to exert more control over the chemical nature of an electrode and to attain the selectivity of electrochemical measurements. This development has helped the measurement of important analytes in medicine, pharmacy, manufactured food and other areas. ${ }^{1}$ The most common material that is usually employed as an inert support for the preparation of chemically modified electrodes (CMEs) is silica gel, that is, silica prepared by the sol-gel process, and zeolites. ${ }^{2-7}$ 
Recently, the use of available alternative materials as cellulose and its derivatives, as supports for preparation of electrochemical sensors, has increased.$^{8}$ Cellulose acetate (CA) is a polymeric derivative of cellulose particularly useful to prepare modified materials because it can be easily molded into different forms, such as membranes, fibers and spheres. These modified materials are normally made by mixing the cellulose acetate and metal alkoxide solutions followed by a phase inversion process. ${ }^{9-12}$ Numerous chemical modifications in cellulosic matrices with highly dispersed metal oxides have been reported in recent years. ${ }^{8,13-23}$

The preparation of chemically modified electrodes with films or fibers of polymers and metal oxides has attracted considerable interest for immobilization of electroactives species due to their excellent electron transfer properties. An important class of organic compounds with interesting electrochemical properties, redox behaviour and possibility of immobilization by means of an ion exchange process in these host matrices is constituted by phenothiazines like methylene blue (MB). ${ }^{24-27}$

Methylene blue dye is a cationic molecule discovered by Heinrich Caro in 1876. Cytological dye and redox indicator. ${ }^{28,29}$ This cationic compound has been used in preparation of CMEs as redox mediators in reactions between the electrode and substrate of analytical interest. This system has shown high selectivity and sensitivity for ascorbic acid, present in the electrolytic solution. ${ }^{24,26,27}$

Ascorbic acid (AA), which is also known as vitamin $\mathrm{C}$, is one of the most popular nutrients being thoroughly found in fruits and vegetables. It can also be present in enriched industrialized products, such as fruit juices, tablets, candies and morning cereals. This recognition is due to the countless benefits that vitamin $\mathrm{C}$ provides to the organism, like antioxidant role, to improve healing processes, to increase iron adsorption from products of vegetable origin and to stimulate the immunological system. ${ }^{30,31}$

In this work, cellulose acetate fiber was chemically modified with titanium oxide, $\mathrm{TiO}_{2}$, which is widely known for its high ion exchange capacity and conductivity properties. $^{32,33}$ This material was used as a matrix to incorporate and retain strongly the methylene blue as an organic electroactive species. Electrodes of this material were obtained by making a paste with carbon. The electrochemical and electrocatalytic properties of this electrode were investigated. In addition, this electrode was used as amperometric sensor for determination of ascorbic acid in aqueous solution.

\section{Experimental}

Preparation of the $\mathrm{CA}-\mathrm{TiO}_{2}$ composite

A $10.0 \mathrm{~g}$ of cellulose acetate (CA) was added to a reaction flask containing $40 \mathrm{~mL}$ of acetic anhydride (Merck) and $50 \mathrm{~mL}$ of acetone (Merck). The mixture was allowed to rest for $24 \mathrm{~h}$ at room temperature under dry nitrogen atmosphere. After that, viscous syrup was formed. Then, $7.5 \mathrm{~mL}$ of titanium (IV) butoxide was added to this syrup (100 g) and magnetically stirred. The resulting syrup was slowly added to a flask containing about $1000 \mathrm{~mL}$ of double distilled water, with efficient stirring, in order to regenerate a fibrous material containing $\mathrm{TiO}_{2}$ immobilized on the cellulose acetate. The fibers were collected by filtration, washed with water and dried under vacuum at room temperature. Finally, the $\mathrm{CA}-\mathrm{TiO}_{2}$ hybrid material was dried at $60{ }^{\circ} \mathrm{C} \cdot{ }^{34,35}$

\section{Immobilization of dye on $\mathrm{CA}-\mathrm{TiO}_{2}$}

Aqueous solution of the dye methylene blue (Aldrich) was prepared in a concentration of $1.0 \mathrm{r} 10^{-3} \mathrm{~mol} \mathrm{~L}^{-1}$. An amount of $0.5 \mathrm{~g}$ of $\mathrm{CA}-\mathrm{TiO}_{2}$ was added to $50 \mathrm{~mL}$ of dye solution. The mixture was shaken for $30 \mathrm{~min}$ and the resulting solid was filtered, washed several times with bidistilled water and dried in an oven for $30 \mathrm{~min}$ at $60{ }^{\circ} \mathrm{C}$. The material will hereafter be designated as $\mathrm{CA}-\mathrm{TiO}_{2} \mathrm{MB}$.

\section{Chemical analyses}

The quantity of metal oxide incorporated in the $\mathrm{CA}-\mathrm{TiO}_{2}$ was determined by igniting the material at $900{ }^{\circ} \mathrm{C}$ for $3 \mathrm{~h}$ and weighing the residue as $\mathrm{CA}-\mathrm{TiO}_{2}$. The amount of methylene blue incorporated in the $\mathrm{CA}-\mathrm{TiO}_{2}$ was determined by nitrogen elemental analysis with a Perkin-Elmer Analyzer 2400 series II CHNS/O apparatus.

\section{EDS analysis}

The EDS image was obtained for $\mathrm{CA}-\mathrm{TiO}_{2}$ material dispersed on a double faced conducting tape on an aluminum support and coated with a thin gold film using a Baltec SCD 050 Sputter Coater apparatus. The micrograph was obtained using a Jeol Scanning Electron Microscope, model JSM 5800, connected to a secondary electron detector and X-ray energy dispersive spectrometer (EDS) for elemental mapping in a Noran Instrument. The image was obtained with a magnification of $550 \mathrm{X}$. 


\section{Electrochemical measurements}

A carbon paste electrode was prepared by mixing 20 $\mathrm{mg}$ of the material CA-TiO $\mathrm{C}_{2}$ with $20 \mathrm{mg}$ of analytical grade graphite (Fluka, 99.9\%) and a drop of liquid paraffin as a binder. This paste was placed in a cavity with $1 \mathrm{~mm}$ depth, in contact with a $5 \mathrm{~mm}$ internal diameter platinum disk which is fused to a glass tube. The carbon paste electrodes made with the $\mathrm{CA}-\mathrm{TiO}_{2}$ material were used as working electrodes, a platinum wire served as the counter electrode and a saturated calomel electrode (SCE) as the reference electrode. The $\mathrm{pH}$ of the solution was adjusted with $\mathrm{NaOH}$ or $\mathrm{HCl}$ solution. The ascorbic acid solution was freshly prepared before using it.

Cyclic voltammetry studies were carried out in an Autolab PGSTAT 30 potentiostat-galvanostat apparatus.

The electrocatalytic oxidation of AA by the $\mathrm{CA}-\mathrm{TiO}_{2} \mathrm{MB}$ carbon paste electrode was investigated by cyclic voltammetric and amperometric techniques, adding freshly prepared ascorbic acid solutions into the electrochemical cell containing $20 \mathrm{~mL}$ of the supporting electrolyte.

\section{Results and Discussion}

\section{Characteristics of the material}

The elemental EDS analysis shows high titanium content over the cellulose acetate surface. The Ti/C atomic ratio found was 0.40 . Figure 1 shows the SEM and EDS images of the $\mathrm{CA}-\mathrm{TiO}_{2}$ material. The material seems to have homogeneous surface, since agglomerated titanium particles were not detected (Figure 1A). From the energy dispersive image (Figure 1B) it was possible to observe that the titanium dispersion was very uniform. The bright points observed in Figure 1B are due to the titanium atoms $\left(\mathrm{Ti} \mathrm{K}_{\mathrm{A}}=4.5 \mathrm{keV}\right)$. With the magnification used, the EDS

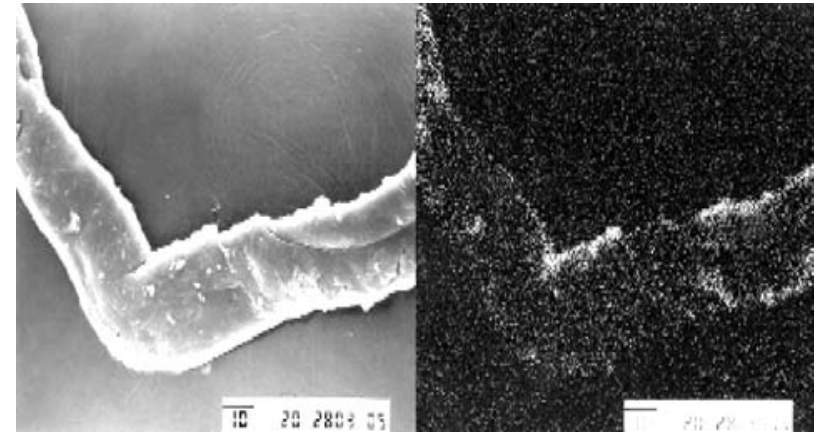

Figure 1. CA-TiO micrographs. (A) SEM image; (B) EDS image.

image is indicating that the metal is homogeneously dispersed over the cellulose acetate fiber.

\section{Cyclic voltammetric studies}

The incorporation of titanium oxide on a cellulose acetate can be described by the following reaction:

$$
\begin{gathered}
\mathrm{n} \mathrm{CAOH}+\mathrm{Ti}\left(\mathrm{OC}_{4} \mathrm{H}_{9}\right)_{4} \longrightarrow(\mathrm{CAO})_{\mathrm{n}} \mathrm{Ti}\left(\mathrm{OC}_{4} \mathrm{H}_{9}\right)_{4-\mathrm{n}}+\mathrm{n} \mathrm{C}_{4} \mathrm{H}_{9} \mathrm{OH} \\
(\mathrm{CAO})_{\mathrm{n}} \mathrm{Ti}\left(\mathrm{OC}_{4} \mathrm{H}_{9}\right)_{4-\mathrm{n}}+(4-\mathrm{n}) \mathrm{H}_{2} \mathrm{O} \longrightarrow(\mathrm{CAO})_{\mathrm{n}} \mathrm{Ti}(\mathrm{OH})_{4-\mathrm{n}}+ \\
+(4-\mathrm{n})_{4} \mathrm{C}_{4} \mathrm{H}_{9} \mathrm{OH}
\end{gathered}
$$

The content of $\mathrm{TiO}_{2}$ incorporated in the cellulose acetate matrix resulted $10.1 \mathrm{wt} . \%\left(1.8 \mathrm{mmol} \mathrm{g}^{-1}\right)$.

The immobilization of methylene blue dye on the $\mathrm{CA}-\mathrm{TiO}_{2} \mathrm{MB}$ was made at $\mathrm{pH}$ 6.0, therefore, the immobilized form of the organic compound is $\mathrm{MB}^{+}$. Figure 2 shows the structures of the organic dye at various $\mathrm{pH}$ values. The immobilization of methylene blue dye on the $\mathrm{CA}-\mathrm{TiO}_{2}$ surfaces occurs by an ion exchange reaction, represented by the following reaction:

\section{$\mathrm{CA}-\mathrm{TiOH}+\mathrm{MB}^{+} \leftrightarrows \mathrm{CA}-\mathrm{TiOMB}+\mathrm{H}^{+}$}

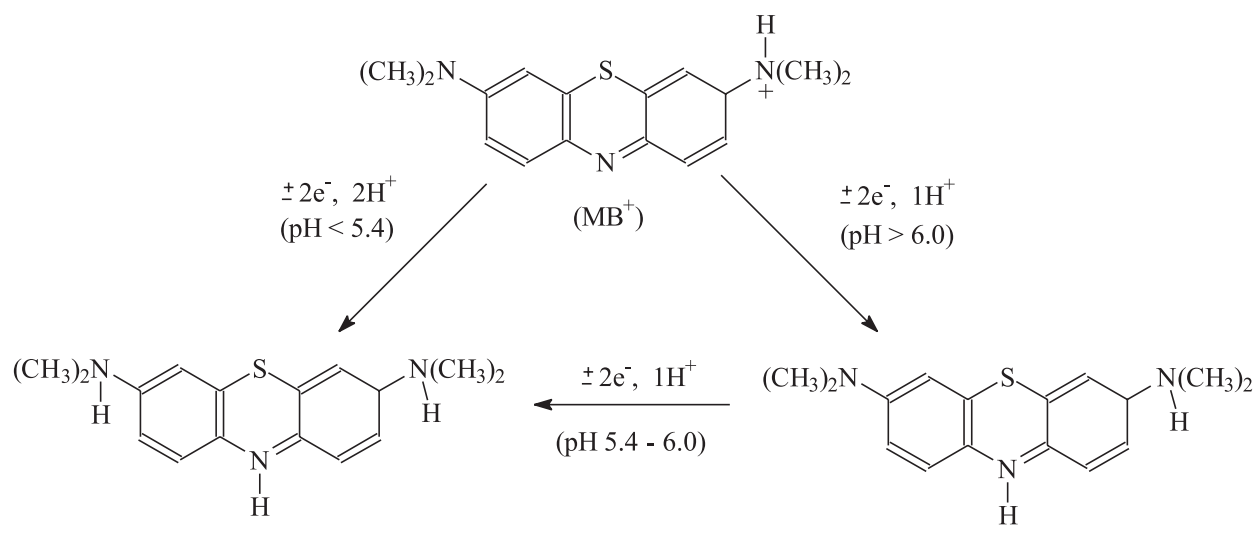

Figure 2. Structural formula of methylene blue in function of $\mathrm{pH}$. 
The amount of methylene blue $\left(\mathrm{MB}^{+}\right)$adsorbed onto $\mathrm{CA}-\mathrm{TiO}_{2}$ was determined by $\mathrm{CHN}$ elemental analysis, resulting in $0.17000 .005 \mathrm{mmol} \mathrm{g}^{-1}$.

Cyclic voltammograms of the carbon paste electrode prepared with modified $\mathrm{CA}-\mathrm{TiO}_{2}$ revealed no Faradaic waves, as observed in Figure $3 \mathrm{~A}$, whereas the one prepared with modified $\mathrm{CA}-\mathrm{TiO}_{2} \mathrm{MB}$ displayed evident voltammetric waves (Figure 3B). The midpoint potential, Em $\left(\mathrm{E}_{\mathrm{m}}=\mathrm{E}_{\mathrm{pa}}+\mathrm{E}_{\mathrm{pc}}\right) / 2$ where $\mathrm{E}_{\mathrm{pa}}$ is the anodic peak potential and $\mathrm{E}_{\mathrm{pc}}$ is the cathodic peak potential) was $\square 225 \mathrm{mV} v$ s. SCE in $1.0 \mathrm{~mol} \mathrm{~L}^{-1} \mathrm{KCl}$ solution at $\mathrm{pH}$ 7.0. This modification in $\mathrm{E}_{\mathrm{m}}$ of about $425 \mathrm{mV}$ towards more positive potentials, compared to those obtained by organic dye in aqueous solution, ${ }^{36}$ suggests that the reduced form of the organic dye interacts more strongly with $\mathrm{CA}-\mathrm{TiO}_{2}$ solid support than with the oxidized form. By integrating the area under the anodic or cathodic curves and considering that the geometric area of the electrode is $0.28 \mathrm{~cm}^{2}$, the estimated quantity of methylene blue was $3.1 \mathrm{r}^{-8} \mathrm{~mol} \mathrm{~cm}^{-2}$.

Cyclic voltammetry curves obtained at different scan rates indicated that the separation of the peak potential, $\$ \mathrm{E}=\mathrm{E}_{\mathrm{pa}}-\mathrm{E}_{\mathrm{pc}}$, in the sweeping rate from 2 to $50 \mathrm{mV} \mathrm{s}^{-1}$, increased according to the increment of the scan rate (Figure 4), indicating that the velocity of the electron transfer is not high enough. This can be a consequence of the difficulty of diffusion of the species of the electrolyte through the interface electrode-solution in order to keep the electroneutrality. Plotting the peak current, $I_{p}$, against the square root of the scan rates, $\mathrm{v}^{1 / 2}$, a linear correlation was obtained (inserted in Figure 4) similar to the one observed for a process of controlled diffusion of the electroative species on the surface of the electrode. ${ }^{37,38}$

The in-operation stability of the electrode was also tested by cycling the potential several times. The peak current intensities, Ipa and Ipc, measured between the potentials

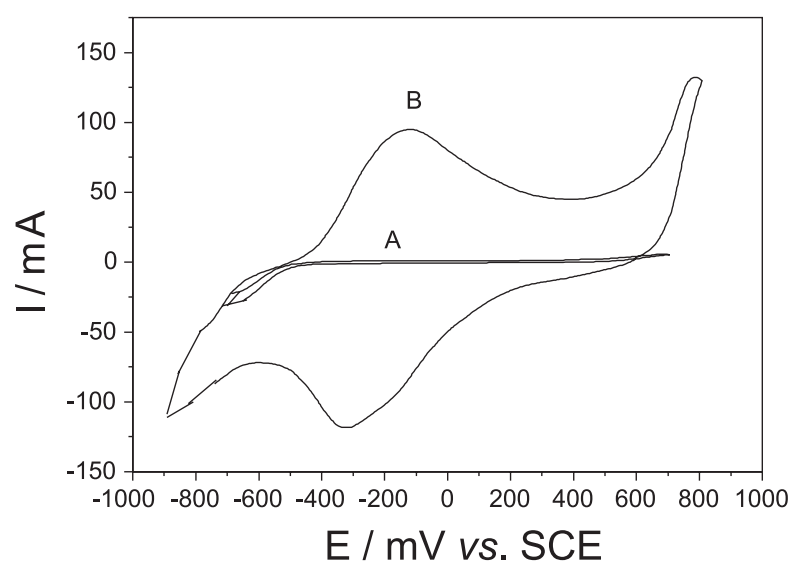

Figure 3. Cyclic voltammograms of the $\mathrm{CA}-\mathrm{TiO}_{2}$ electrode (A) and of the CA-TiO $\mathrm{MB}_{2}$ modified electrode (B) in scan rate at $20 \mathrm{mV} \mathrm{s}^{-1}, \mathrm{pH} 7.0$ and $1.0 \mathrm{~mol} \mathrm{~L}^{-1} \mathrm{KCl}$ solution.

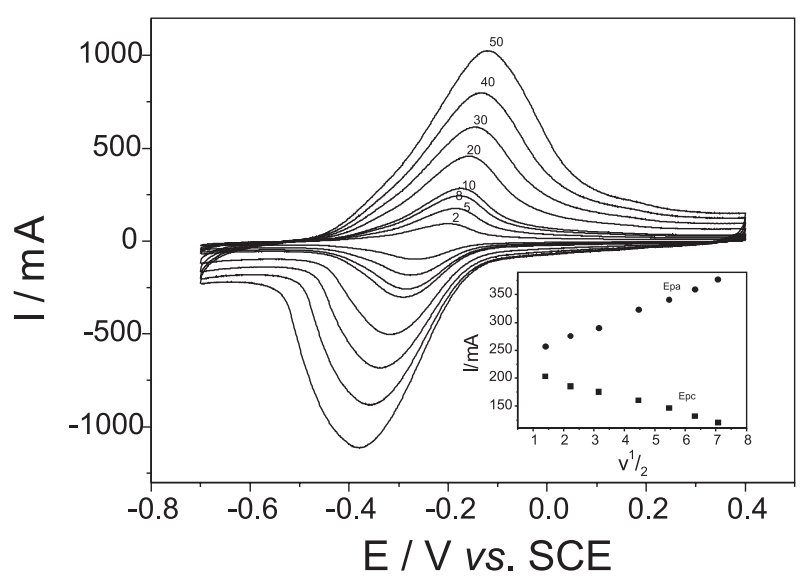

Figure 4. Cyclic voltammograms obtained at different scan rates $(2,5$, 8, 10, 20, 30, 40, $50 \mathrm{mV} \mathrm{s}^{-1}$ ). Supporting electrolyte: $1.0 \mathrm{~mol} \mathrm{~L}^{-1} \mathrm{KCl}$ solution. Plot of the cathodic and anodic peak currents, $\mathrm{I}_{\mathrm{pc}}$ and $\mathrm{I}_{\mathrm{pa}}$, against the square root of the scan rates, $v^{1 / 2}$, (inset on Figure 4).

-0.7 and $0.4 \mathrm{~V}$ at scan rate of $20 \mathrm{mV} \mathrm{s}^{-1}$ in $1.0 \mathrm{~mol} \mathrm{~L}^{-1}$ $\mathrm{KCl}$ as the supporting electrolyte solution, decreased only by $2 \%$ after 100 cycles, indicating that the organic dye is strongly adhered onto the matrix surfaces and neither leached out from the material nor decomposed. The studies of chemical stability indicated that the electrode presented good performance when operating for two days, used $8 \mathrm{~h} /$ day and maintained overnight in $0.01 \mathrm{~mol} \mathrm{~L}^{-1} \mathrm{KCl}$ solution. Under this condition, it was observed a decrease of $7 \%$ in the current intensities. The electrode can be considered as having good chemical stability, allowing its use for reasonable time without significant variation in the response. In addition, modified carbon paste electrodes are easily prepared and can be obtained in a short period of time.

The $\mathrm{pH}$ effect on the electrode response (Figure 5) was studied because it can affect both midpoint potential, $\mathrm{E}_{\mathrm{m}}$, anodic and cathodic peak current intensities. The $\mathrm{CA}-\mathrm{TiO}_{2} \mathrm{MB}$ modified electrode response was investigated in the $\mathrm{pH}$ range between 3.0 and 7.0, using the $1.0 \mathrm{~mol}$ $\mathrm{L}^{-1} \mathrm{KCl}$ as the supporting electrolyte solution. In this $\mathrm{pH}$ range, $\mathrm{E}_{\mathrm{m}}, \mathrm{I}_{\mathrm{pa}}$ and $\mathrm{I}_{\mathrm{pc}}$ are not affected, remaining practically constant, as opposed to a different behavior that is presented in aqueous solution by the methylene blue dye, whose redox process becomes more efficient with the decrease of the $\mathrm{pH} .{ }^{24}$ The results suggest that the MB organic dye is immobilized on the in $\mathrm{CA}-\mathrm{TiO}_{2}$ solid matrix as a protonated form, held by an electrostatic interaction and protected against the change of the external $\mathrm{pH}$ solution. Additionally, it was observed that when the organic dye is present in aqueous solution or adsorbed on the graphite electrode the $\mathrm{E}_{\mathrm{m}}$ is dependent on the $\mathrm{pH}$ of the solution due to the protonation and deprotonation process of amino functional groups during the conversion from oxidized to reduced forms and vice versa. This behavior in relation to the $\mathrm{pH}$ of 
the solution suggests that the methylene blue compound is very strongly involved in the binding to $\mathrm{CA}-\mathrm{TiO}_{2}$ through the two amino groups of methylene blue at positions 3.0 and 7.0 as well as the heterocyclic nitrogen. ${ }^{39}$

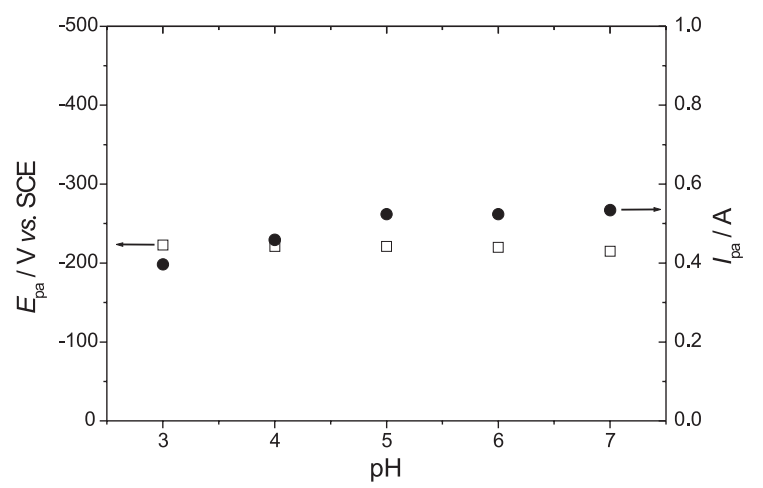

Figure 5. Plot of the solution $\mathrm{pH}$ against $\mathrm{E}_{\mathrm{m}}, \mathrm{I}_{\mathrm{pa}}$ and $\mathrm{I}_{\mathrm{pc}}$. Supporting electrolyte: $1.0 \mathrm{~mol} \mathrm{~L}^{-1} \mathrm{KCl}$ solution and in scan rate at $20 \mathrm{mV} \mathrm{s}^{-1}$.

\section{Oxidation of $A A$}

Figure 6 shows the ascorbic acid oxidation on the $\mathrm{CA}_{-} \mathrm{TiO}_{2} \mathrm{MB}$ electrode surface, immersed in $1.0 \mathrm{~mol} \mathrm{~L}^{-1}$ $\mathrm{KCl}$ solution at $\mathrm{pH} 7.0$ in the absence (Figure 6, curve A) and in the presence of different concentrations of ascorbic acid (Figure 6, curves B-E). An increase in intensity of the anodic current peak, as the ascorbic acid concentration was increased stepwise from $1.0 \mathrm{r} 10^{-3} \mathrm{~mol} \mathrm{~L}^{-1}$ to $40.0 \mathrm{r}$ 四 $0^{-3} \mathrm{~mol} \mathrm{~L}^{-1}$, is an indication of catalytic oxidation of ascorbic acid mediated by $\mathrm{CA}-\mathrm{TiO}_{2} \mathrm{MB}$ electrode.

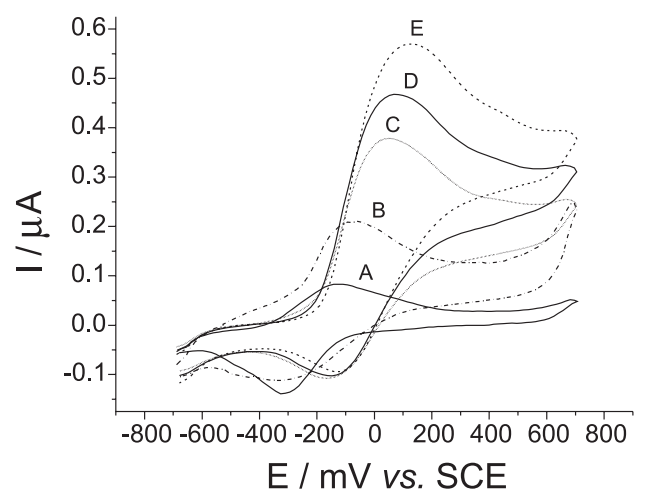

Figure 6. Cyclic voltammograms curves for the $\mathrm{CA}-\mathrm{TiO}_{2} \mathrm{MB}$ electrode in the absence of ascorbic acid (A) and in the presence of the ascorbic acid in concentrations mol L-1: (B) $1 \times 10^{-3}$, (C) $20 \times 10^{-3}$, (D) $30 \times 10^{-3}$, (E) $40 \times 10^{-3}$. Supporting electrolyte: $1.0 \mathrm{~mol} \mathrm{~L}^{-1} \mathrm{KCl}$ solution, $\mathrm{pH} 7.0$ and scan rate at $20 \mathrm{mV} \mathrm{s}^{-1}$.

The reaction process occurs by means of an electrochemical-chemical step, involving an electron transfer reaction followed by a hydration process, in which, respectively, the acid is irreversibly oxidized to dehydroascorbic acid followed by a hydration reaction in which the formation of hydrated dehydroascorbic acid takes place..$^{40}$ The reaction mechanism at the electrode-solution interface can be written as follows:

$\mathrm{CA}-\mathrm{TiO}_{2} \mathrm{MB}_{\text {ox }}+\mathrm{H}_{2} \mathrm{AA} \longrightarrow \mathrm{CA}-\mathrm{TiO}_{2} \mathrm{MB}_{\text {red }}+\mathrm{HAA}^{+}+\mathrm{H}^{+}$
$\mathrm{CA}-\mathrm{TiO}_{2} \mathrm{MB}_{\text {red }} \longrightarrow \mathrm{CA}-\mathrm{TiO}_{2} \mathrm{MB}_{\text {ox }}+2 \mathrm{e}^{\square}$

The $\mathrm{pH}$ of electrolyte solution could present considerable influence in the reaction of electro-oxidation of the ascorbic acid as earlier reported. ${ }^{41}$ On the other hand, in this work, the effect of the $\mathrm{pH}$ solution on peak currents and peak potentials for AA electro-oxidation were studied using $\mathrm{CA}-\mathrm{TiO}_{2} \mathrm{MB}$ modified electrode. It was observed that for $\mathrm{pH}$ solutions ranging from 3.0 to 7.0 no significant effects on the anodic peak potential as well as on the peak currents were seen, when the AA concentration was fixed at $1.0 \mathrm{r} 10^{-3} \mathrm{~mol} \mathrm{~L}^{-1}$.

\section{Amperometric detection}

Aiming to check the potential of using this electrode made with $\mathrm{CA}-\mathrm{TiO}_{2} \mathrm{MB}$ as sensor for ascorbic acid, chronoamperometry experiments were undertaken. First, amperometric studies were performed in order to determine the best potential to be applied. The potential was chosen by measuring the intensities of the catalytic currents for a solution containing $1.0 \mathrm{r} 10^{-3} \mathrm{~mol} \mathrm{~L}^{-1} \mathrm{AA}$ at $298 \mathrm{~K}$ and $\mathrm{pH}$ 7.0. The potential was fixed at $0.300 \mathrm{~V}$ in the subsequent experiments.

Figure 7 shows the amperometric curve obtained upon addition of the AA into the electrochemical cell keeping fixed $\mathrm{E}_{\mathrm{pa}}=0.300 \mathrm{~V}, \mathrm{pH} 7.0$ in $1.0 \mathrm{~mol} \mathrm{~L}^{-1} \mathrm{KCl}$ supporting electrolyte solution. In the concentration range of ascorbic acid between $5.0 \mathrm{r} 10^{-4} \mathrm{~mol} \mathrm{~L}^{-1}$ and $4.5 \mathrm{r} 10^{-3} \mathrm{~mol} \mathrm{~L}^{-1}$, a linear correlation was observed, as demonstrated by the equation

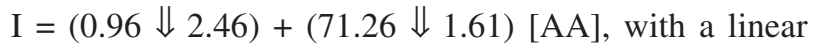
correlation coefficient $\mathrm{R}=0,999$ for $\mathrm{n}=9$. The detection limit

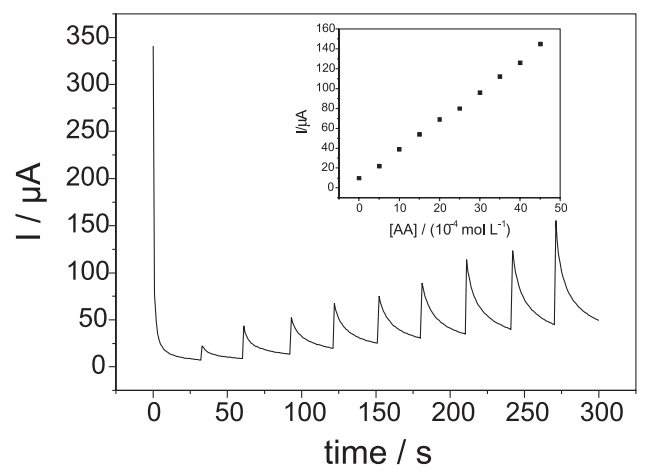

Figure 7. Chronoamperometry study for $\mathrm{CA}-\mathrm{TiO}_{2} \mathrm{MB}$ in $1.0 \mathrm{~mol} \mathrm{~L}^{-1} \mathrm{KCl}$ solution. Chronoamperogram obtained by successive addition of $100.0 \mu \mathrm{L}$ ascorbic acid $0.1 \mathrm{~mol} \mathrm{~L}^{-1}$ into an electrochemical cell containing $20 \mathrm{~mL}$ of $1.0 \mathrm{~mol} \mathrm{~L}^{-1} \mathrm{KCl}$ solution at $\mathrm{pH}$ 7.0. 
Table 1. Performance of the $\mathrm{CA}-\mathrm{TiO}_{2} \mathrm{MB}$ modified electrode in comparison with others amperometric sensors prepared in different solid supports for the determination of AA

\begin{tabular}{|c|c|c|c|c|c|}
\hline Electrode & Solid Support & Linear range $/\left(\mathrm{mmol} \mathrm{L}^{-1}\right)$ & Detection limit/( $\left.\mathrm{Mnol} \mathrm{L}^{-1}\right)$ & Sensitivity $/\left(\mathrm{mA} \mathrm{cm}^{-2}\right) /\left(\mathrm{mol} \mathrm{L}^{-1}\right)$ & Ref. \\
\hline $\mathrm{CA}-\mathrm{TiO}_{2} \mathrm{MB}$ & cellulose acetate & $0.5-4.5$ & 15 & 7.1 & this work \\
\hline $\mathrm{ZrP} / \mathrm{MB}$ & phosphate & $0.2-1.7$ & 10 & - & 24 \\
\hline $\mathrm{Si}-\mathrm{An}^{+} / \mathrm{CR}^{-}$ & sol-gel & $0.79-6.7$ & - & - & 44 \\
\hline $\mathrm{C} / \mathrm{Fe}(\mathrm{II}) \mathrm{NP}$ & carbon paste & $1.0-26$ & 1400 & 18 & 45 \\
\hline$\left(\mathrm{C} / \mathrm{SiPy}^{+}\right)_{4}\left[\mathrm{Fe}(\mathrm{CN})_{6}\right]^{4}$ & graphite bare & $0.025-0.25$ & 25 & - & 46 \\
\hline MBMOR/P & zeolite & $0.02-0.8$ & 12.1 & - & 47 \\
\hline CA/DCPI-CME & cellulose acetate & $0.1-6$ & 10 & - & 48 \\
\hline$[\mathrm{DCPI}]_{3}-\mathrm{La}-\mathrm{SPE}$ & screen-printed & $0.01-1$ & 10 & - & 49 \\
\hline CuP-Poly & polyester resin & $0.02-3.2$ & 10 & - & 50 \\
\hline
\end{tabular}

achieved ( 3 standard deviations of the blank divided by the slope of calibration curve) was $15 \mu \mathrm{mol} \mathrm{L} \mathrm{L}^{-1}$, the quantification limit (10 standard deviations of the blank divided by the slope of calibration curve) was $50 \mu \mathrm{mol} \mathrm{L}^{-1}$, and the sensitivity was $7.1 \mu \mathrm{A} \mathrm{L} \mathrm{mol}{ }^{-1}$. The average response time, measured after various substrate additions in the electrochemical cell, was $1.0 \mathrm{~s}$.

It was performed an experiment to determine the ascorbic acid concentration in commercial pharmaceutical tablets, using the $\mathrm{CA}-\mathrm{TiO}_{2} \mathrm{MB}$ electrode. Commercial tablets were dissolved in $25.0 \mathrm{~mL}$ of distilled water (solution $\mathrm{A}$ ). The amperometric response was obtained by adding $100.0 \mu \mathrm{L}$ aliquots of solution A into a cell filled with $20.0 \mathrm{~mL}$ of a $1.0 \mathrm{~mol} \mathrm{~L}^{-1} \mathrm{KCl}$ solution at $\mathrm{pH} 7.0$ under nitrogen. The ascorbic acid concentration in the commercial Vitamin $\mathrm{C}$ formulation, which prescribed amount is $1 \mathrm{~g} /$ tablet was determined by amperometry (1.02 $00.01 \mathrm{~g} /$ tablet) and further compared with iodometric titration method (0.99 o $0.03 \mathrm{~g} /$ tablet).$^{42}$ The presence of other substances in the Vitamin $\mathrm{C}$ tablets, such as citric acid, lemon flavor, orange flavor, sodium bicarbonate, sodium cyclamate and quinoline yellow, did not affect the results. ${ }^{43}$

The performance of the $\mathrm{CA}-\mathrm{TiO}_{2} \mathrm{MB}$ modified electrode in comparison with others amperometric sensors, based on carbon paste electrodes for the determination of AA, were also shown in Table 1. As it can be observed, the results indicated that the carbon paste electrode modified with $\mathrm{CA}-\mathrm{TiO}_{2} \mathrm{MB}$ presented good performance with low detection limit and high sensitivity, showing potentiality to be utilized as electrochemical sensor for determination of ascorbic acid in commercial tablets.

\section{Conclusions}

The elemental EDS analysis shows high titanium content homogeneously dispersed over the cellulose acetate surface. The immobilization of methylene blue dye on the $\mathrm{CA}-\mathrm{TiO}_{2}$ surfaces occurs by ion exchange. The effect of $\mathrm{pH}$ on the electrode response was studied in the range of 3.0 to 7.0 and the results suggest that the organic dye is entrapped in the $\mathrm{CA}-\mathrm{TiO}_{2}$ matrix in a protonated form, held by an electrostatic interaction and protected against the change of $\mathrm{pH}$ of the external solution. The modified electrode showed chemical stability for various oxidation-reduction cycles. When the concentration of ascorbic acid varies from $5.0 \mathrm{r} 10^{-4}$ to $4.5 \mathrm{r} 10^{-3} \mathrm{~mol} \mathrm{~L}^{-1}$, a linear correlation is observed, with

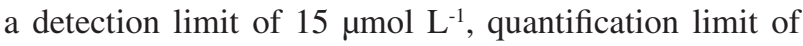
$50 \mu \mathrm{mol} \mathrm{L} \mathrm{L}^{-1}$ and a sensitivity of $7.1 \mu \mathrm{A} \mathrm{L} \mathrm{mol}^{-1}$. The electrode response to ascorbic acid is very fast, with an elapsed time of about $1.0 \mathrm{~s}$. The results indicate that carbon paste electrode modified with $\mathrm{CA}-\mathrm{TiO}_{2} \mathrm{MB}$ shows good potentiality to be utilized as a sensor for determination of ascorbic acid in commercial products.

\section{Acknowledgments}

The authors are grateful to the Reviewers for the suggestions; to the Pró-Reitoria de Pesquisa da Universidade Federal do Rio Grande do Sul (Propesq-UFRGS); to Fundação de Amparo à Pesquisa do Estado do Rio Grande do Sul (FAPERGS); to the Fundação de Amparo à Pesquisa do Estado de São Paulo (FAPESP); to the Coordenação de Aperfeiçoamento de Pessoal de Nível Superior (CAPES); to the Conselho Nacional de Desenvolvimento Científico e Tecnológico ( $\mathrm{CNPq}$ ) and to the Ministério de Ciência e Tecnologia (MCT) for financial support and fellowships. We also thank the CME-UFRGS for the use of the SEM.

\section{References}

1. Dempsey, E.; Wang J.; Wollenberger, V.; Ozsoz, M.; Smith, M. R.; Biosens. Bioelectron. 1992, 715, 323.

2. Walcarius, A.; Electroanalysis 1998, 10, 1217.

3. Collinson, M. M.; Crit. Rev. Anal. Chem. 1999, 29, 289.

4. Walcarius, A.; Anal. Chim. Acta 1999, 384, 1.

5. Wang, J.; Walcarius, A.; J. Electroanal. Chem. 1996, 407, 183. 
6. Mannino, S.; Wang, J.; Electroanaysis 1992, 4, 835.

7. Wang, J.; Anal. Chim. Acta 1999, 399, 21.

8. Gushikem, Y.; Toledo, E. A. In Polymer Interfaces and Emulsions; Esumi, K., ed.; Marcel Dekker: New York, 1999, ch. 3, p. 509.

9. Rodrigues Filho, U. P.; Gushikem, Y.; Gonçalves, M. D.; Cachichi, R. C.; de Castro, S. C.; Chem. Mat. 1996, 8, 1375.

10. Gushikem, Y.; Campos, E. A.; J. Braz. Chem. Soc. 1998, 9, 273.

11. Lazarin, A. M.; Gushikem, Y.; J. Braz. Chem. Soc. 2002, 13, 88.

12. Lazarin, A. M.; Borgo, C. A.; Gushikem, Y.; Kholin, Y. V.; Anal. Chim. Acta 2003, 477, 305.

13. Alfaya, R. V. S.; Gushikem, Y.; J. Coll. Interf. Sci. 1999, 213, 438.

14. Lazarin, A. M.; Gushikem, Y.; de Castro, S. C.; J. Mat. Chem. 2000, 10, 2526.

15. da Silva, L. R. D.; Gushikem, Y.; Kubota, L. T.; Coll. Surf. B-Biointerf. 1996, 6, 309.

16. da Silva, L. R. D.; Peixoto, C. R. M.; Gushikem, Y.; Sep. Sci. Technol. 1996, 31, 1045.

17. da Silva, L. R. D.; Gushikem, Y.; Gonçalves, M. C.; Rodrigues Filho, U. P.; de Castro, S. C.; J. Appl. Polym. Sci. 1995, 58, 1669.

18. da Silva, L. R. D.; Rodrigues Filho, U. P.; Peixoto, C. R. M.; Gushikem, Y.; Quim. Nova 1995, 18, 337.

19. Rodrigues Filho, U. P.; Gushikem, Y.; Fujiwara, F. Y.; Langmuir 1994, 10, 4357.

20. Campos, E. A.; Gushikem, Y.; Gonçalves, M. C.; de Castro, S. C.; J. Coll. Interf. Sci. 1996, 180, 453.

21. Kurokawa, Y.; Ueno, K.; J. Appl. Polym. Sci. 1982, 27, 621.

22. Dalas, E.; J. Cryst. Growth 1991, 113, 140.

23. Chatterjee, S.; Sarkar, S.; Bhattacharyya, S. N.; Polymer 1993, 34, 1979.

24. Pessoa, C. A.; Gushikem, Y.; Kubota, L. T.; Electroanalysis 1997, 9, 800

25. Pessoa, C. A.; Gushikem, Y.; Kubota, L. T.; Gorton, L.; J. Electroanal. Chem. 1997, 431, 23.

26. Khoo, S. B.; Chen, F.; Anal. Chem. 2002, 74, 5734.

27. Dilgin, Y.; Dursun, Z.; Nisli, G.; Gorton, L.; Anal. Chim. Acta 2005, 542, 162.

28. Gordon, P. F.; Gregory, P.; Organic Chemistry in Colour, Springer-Verlag: Berlin, New York, 1983.

29. Scotti, R.; Lima, E. C.; Benvenutti, E. V.; Piatnicki, C. M. S.; Dias, S. L. P.; Gushikem, Y.; Kubota, L. T.; Quim. Nova 2006, $29,208$.
30. Ijeri, V. S.; Jaiswal, P. V.; Srivastava, A. K.; Anal. Chim. Acta 2001, 439, 291.

31. Zare, H. R.; Nasirizadeh, N.; Ardakani, M. M.; J. Electroanal. Chem. 2005, 577, 25.

32. Clearfield, A.; Inorganic Exchange Materials, CRC Press: Boca Raton, 1982, p.1.

33. Clearfield, A.; Chem. Rev. 1988, 88, 125.

34. Dias, S. L. P.; Gushikem, Y.; Ribeiro, E. S.; Benvenutti, E. V.; J. Electroanal. Chem. 2002, 523, 64.

35. Porto, A. L. M.; Cassiola, F.; Dias, S. L. P.; Joekes, I.; Gushikem, Y.; Rodrigues, J. A. R.; Moran, P. J. S.; Manfio, G. P.; Marsaioli, A. J.; J. Mol. Cat. B: Enzymatic 2002, 19, 327.

36. Ottaway, J. M. In Indicators; Bishop, E., ed.; Pergamon: Oxford, 1972, pp. 469.

37. Kissinger, P. T.; Heineman, W. R.; J. Chem. Educ. 1983, 60, 702.

38. Bard, A. J.; Faulkner, L. R.; Electrochemical Methods: Fundamentals and Applications, John Wiley \& Sons: New York, 1980.

39. Wopschall, R. H.; Shain, I.; Anal. Chem. 1967, 39, 1527.

40. Xing, X.; Bae, I. T.; Shao, M.; Liu, C. -C.; J. Electroanal. Chem. 1993, 346, 309.

41. Xing, X.; Bae, T-C.; Shao, M.; Liu, C. -C.; Electroanalysis 1992, 4, 191.

42. Silva C. R.; Simoni, J. A.; Collins, C. H.; Volpe, P. L. O.; J. Chem. Educ.1999, 76, 1421.

43. Ribeiro, E. S.; Kubota, L. T.; Microchim. Acta 2006, 154, 303.

44. Pavan, F. A.; Ribeiro, E. S.; Gushikem, Y.; Electroanalysis 2005, 17, 625 .

45. Carmo, D. R.; da Silva, R. M.; Stradiotto, N. R.; Port. Electroc. Acta 2004, 22, 71 .

46. Alfaya, R. V. S.; Gushikem, Y.; Alfaya, A. A. S.; J. Braz. Chem. Soc. 2000, 11, 281.

47. Arvand, M.; Sohrabnezhad, Sh.; Mousavi, M. F.; Shamsipur, M.; Zanjanchi, M. A.; Anal. Chim. Acta 2003, 491, 193.

48. Florou, A. B.; Promodimis, M. I.; Karayannis, M. I.; TzouwaraKarayanni, S. M.; Anal. Chim. Acta 2000, 409, 113.

49. Florou, A. B.; Promodimis, M. I.; Tzouwara-Karayanni, S. M.; Karayannis, M. I.; Anal. Chim. Acta 2000, 423, 107.

50. Teixeira, M. F. S.; Ramos, L. A.; Fatibello-Filho, O.; Cavalheiro, E. T. G.; Anal. Bioanal. Chem. 2003, 376, 214.

Received: September 13, 2007 Web Release Date: April 25, 2008 